\title{
Hydroid Pigments. I. General discussion and pigments of the Sertulariidæ.
}

\author{
By
}

Nellie M. Payne.

\section{INTRODUCTION.}

\section{Collenterate Pigments.}

THE literature on cœlenterate pigments is not large, but is rather scattered and somewhat difficult of access. In addition some pigment studies on squids and worms appear in the literature as researches on cœlenterates. An effort has been made in this paper to bring together the known results that have been secured in the study of cœlenterate colouring matter with the exception of such papers as deal with protective coloration, mimicry, and the like. Compilations are not listed unless they contained an original contribution either in methodology or view-point. Only papers where it could be clearly ascertained that the animal studied was a cœlenterate have been cited. In some of the older work done by non-zoologists, the scientific name has been sunk to a mere synonym and the description of the animal was insufficient even to place it to phylum.

The pigments of the cœlenterates include several types of compounds, some of which may be used in respiration. Blanchard (1882) described a blue, water-soluble pigment obtained from the circum-umbrellar region of Rhizostoma cuveri. The aqueous solution of this pigment showed three absorption bands in the red, yellow, and green respectively. Colasanti (1880) described a blue pigment from hydromedusæ, which colouring matter he considered as a compound of carotin and protein. Elmhirst and Sharpe (1920) found a light-sensitive pigment in Actinia equina and Anemonia sulcata. The intensity of the colour was proportional to the intensity of the light to which the Actinians were exposed. Elmhirst studied the environment in relation to the colour, and Sharpe the chemical properties of the pigments themselves. Sharpe came to the conclusion that in Actinia equina the red and brown pigments may be the same basic substance, the exact colour of which is due to the alkalinity or acidity of the medium in which the pigments occurs. This animal used blue and possibly violet-light rays ; the light-sensitive pigment which it contains has properties similar to those of chlorophyll and is used in 
respiration. Anemonia sulcata contained no hæmoglobin derivatives. It did contain small green algæ along the inner border of the tentacles and in the mesenteries. These algæ contained a colouring matter very similar to the chlorophyll of green leaves.

Fewkes (1889) described a case of pigment discharge by a hydroid medusoid. Fürth (1903) in his monograph on the physiology of lower animals classifies the pigments of cœlenterates into seven groups: (1) the blue pigment of the medusoid umbrella, (2) pelageine, (3) the blue colour of the coral Heliopora corulea and compounds related thereto, (4) the hæmatin series, (5) the red and purple pigments which include colouring matters such as actinochrome, purpuridin, and the floridines, (6) the lipochromes, and (7) the uradines, a sulphur-containing group, which are yellow in the live animal, but turn black on its death.

Fulton (1922) described a red pigment from Actinia bermudensis. The pigment is soluble in $\mathrm{CS}_{2}$, methyl, ethyl, and amyl alcohol, petroleum ether, pyridine, and acetone. The pigment occurs in granules. Addition of $\mathrm{HCl}$ or valeric acid deepened the red colour, but alkali produced no change that was apparent. Geddes (1882) found that the "yellow cells" in cœlenterates were commensal organisms. These organisms, which were algæ, produced oxygen which was needed by the cœlenterate in its respiration. The chlorophyll-like pigment, found in the cœlenterate Anthea and in others, was thus due, not to the cœlenterate itself but to the alga. Griffiths and Platt (1895) obtained a violet pigment from the medusoid Pelagia, to which dyestuff they applied the name pelageine and ascribed the formula $\mathrm{C}_{20} \mathrm{H}_{17} \mathrm{NO}_{7}$. Since the pigment was extracted in amorphous condition only, it seems scarcely possible that the formula suggested could be valid. Griffiths (1892) considered that the colenterate pigments had a respiratory function.

Haurowitz and Waelsch (1926) found a blue pigment in Vellela spirans, which on spectroscopic examination showed absorption in both red and violet, but no distinct bands. The pigment became reddish brown on drying, or with treatment with alcohol or toluol. Kropp (1931) extracted the colouring matter of Vellela spirans with water. The extract was opalescent with a reddish colour in reflected light. Near the neutral point it turned yellow, and successively pink and reddish as the solution became increasingly acid. An aqueous solution of the pigment showed diffuse absorption in the red, $\lambda=655 \mu, \mu-685 \mu \mu$, and blue violet $425-475 \mu \mu$, but no sharp bands.

The most comprehensive work that has been made on the cœlenterate pigments is that of Krukenberg $(1880,1882)$. He obtained a green pigment with a red fluorescence from Anthea cereus. * The alcoholic solution of this pigment varied from brown to green. The absorption spectrum

\footnotetext{
* = Anemonia sulcata.
} 
of the alcoholic solution was figured. Addition of acid changed the green colour to blue and added a new band at the junction of yellow and green. This author pointed out the similarity between the green pigments of the cœlenterates and the chlorophyll in plants.

Lancaster (1873) examined the pigment found in the stalked protozöon, Stentor cceruleus, with a Sorby-Browning spectroscope. He found an absorption spectrum containing two bands, the darker in the red extending a little to the side of solar C line, and the second in the green. Stentor mülleri gave absorption spectra like those of Hydra and Spongilla. Since Stentor feed on Hydra, it served as a concentrating agent for the hydroid pigment. Liversidge (1898) found a blue nitrogen containing pigment in the coral Heliopora corulea. The pigment from "dead coral" dissolved readily in alcohol and acetic acid. Heating a concentrated residue of coral extract produced an odour similar to that of burned fish. Liversidge tested the solubility of the material in a large series of compounds both inorganic and organic. Acetic acid proved to be one of the best solvents. An alcoholic solution of coral contained more organic matter than an acetic acid solution. The pigment was insoluble in kerosene, the pure paraffines, in $\mathrm{CS}_{2}, \mathrm{CCl}_{4}$, or petroleum ether. Solutions were either blue or green, depending on the solvent used, e.g. a sodium acetate solution was green; a formic acid solution blue. The pigment did not appear to be either a natural indicator or a reducing agent.

M'Kendrick (1881) described pigments that occurred in small granules in several of the colenterates. He did not study the chemistry but mentioned a yellow pigment in Chrysaora, a blue one in Cyanea, and a pink in Aurelia. He gave simple methods for pigment extraction.

MacMunn $(1885,1890)$ found colouring matters in cœlenterates which resembled these of vertebrate blood. Actinia mesembryanthemum* contained a pigment which could be transformed either into hæmochromogen or hæmatoporphorin. This pigment was not actinochrome, which dyestuff is widely distributed in the Actiniæ. In Sargartia parasitica occurred a colouring matter in both reduced and oxidised states. This pigment did not occur in any of the Actiniæ. A green pigment which gave all the reactions of biliveridin was found in the mesenteries of Anthea mesentherium. A yellow pigment which differed from chlorophyll occurred in the tentacles of Anthea cereus, $\uparrow$ Bunodes balii, and Sargartia bellis. In these species were both luteins and a pigment that gave absorption bands in the red and violet part of the spectrum.

Merejowski (1881) described a carotin-like substance from cœlenterata which he designated as tétranérythine.

Mosely (1873) found a pigment, the so-called actiniochrome, in Actinia mesembryanthemum $\ddagger$ which is a pale olive or merely a dirty white colour

$$
\text { * =Actinia equina. } \quad t=\text { Anemonia sulcata. } \quad t=\text { A. equina. }
$$


in muddy water. This colouring matter also occurred in Bunodes crassicornis which is a transparent green. In some specimens of B. crassicornis the tips of the gonidial tubercules were bright red. Mosely determined the absorption band for the red pigment but lost the drawing. He found no similar colouring matter in Actinia mesembryanthemum* or Actinia rosea. In 1877 Mosely found a hematine-like pigment in Bunodes crassicornis. Teissier (1925) described an interesting case of pigment development which paralleled the embryonic. This author believed that the appearance of pigment in the eggs of Clava squamata was due to the liberation of carotin from a compound of carotin and protein.

\section{General Chemical Literature.}

The nomenclature for the various pigments differs from author to author. In the foregoing literature summary, the original term used by the investigator in question has been quoted. Lypochromes, luteins, and carotin belong to the group of carotinoids as the term is defined by Palmer (1922). In this paper the nomenclature of Palmer will be followed. This worker summarised the preceding work on carotinoid pigments and has also made valuable contributions of his own to the study of chromatology. Schertz (1925) described an accurate method for obtaining crystalline carotin. He extracted the pigment with a highly purified ether kept over sodium. Crystalline carotin kept in an ice box oxidised very slowly and could be stored some months without deterioration. Wheldale (1916) classifies plant pigments into two general groups: the plastid pigments which include chlorophylls, xanthophylls, and the carotinoids, and the pigments distributed throughout the cell or the anthocyanins, and their derivatives, the flavones. The anthocyanins and flavones are characterised by their water solubility. In the plant kingdom there are two yellows, one type soluble in water, the other in fat solvents. Wheldale also pointed out that many white flowers contain a pigment made apparent in alkaline solution. The flavones are natural indicators, being white in neutral or acid solution, and yellow to orange in alkaline. The flavones are oxidation products of the anthocyanins. The flavone group forms characteristic salts with $\mathrm{FeSO}_{4}, \mathrm{FeCl}_{2}, \mathrm{FeCl}_{3}$, and $\mathrm{Pb}(\mathrm{COO})_{2}$.

The ultimate source of the coelenterate pigments may be the plant kingdom. Thus far, to the author's knowledge, there has been no clear example of either chlorophyll or carotin being a direct product of animal metabolism. Geddes (1882) and others have demonstrated the algal origin of cœlenterate chlorophyll. An interesting paper by Palmer and Knight (1924) describes the transfer of potato carotin into the blood of the 
potato beetle, Leptinotarsa decimlineata Say, and from this insect to the predaceous plant bug, Perillus bioculatus Fabricius, in which the carotin was in part depositer in the exoskeleton. Thus far the origin of the cœlenterate pigments other than chlorophyll is unknown. It is altogether possible that both carotin and flavones are of algal origin.

\section{Materials and Methods.}

The hydroids studied by the present writer belonged to two distinct groups, one including those bearing carotinoid pigments, namely, the Antennulariidæ and Haleciidæ; the other including the Sertulariidæ which carried water-soluble yellow and brown pigments.

The characteristic of the colouring matters in these two groups, respectively, was so different that the same method of treatment of the hydroids previous to extraction could not be used. The caratinoidbearing group, of which Antennularia antennina, A. ramosa, Aglaophenia pluma, A. tubulifera, and Halecium halecinum were studied, were washed in fresh water repeatedly before their pigments were extracted. The hydroids thus freed of debris were dried in an incubator to air-dry state and then extracted with $\mathrm{CS}_{2}, \mathrm{CCl}_{4}$, or ether. The pigments in each of the species studied was more soluble in $\mathrm{CS}_{2}$ than in any other of the solvents used. Those used included $\mathrm{CS}_{2}, \mathrm{CCl}_{4}$, ether, absolute alcohol, pyridine, petroleum ether, and chloroform. Details of the methods will be given in a later paper.

The colouring matter of the Sertulariidæ with the exception of the brown of Sertularia pumila was so extremely soluble in fresh water that the hydroids could not be freed of the usual debris and dirt clinging to them by washing in fresh water. The most practical way of cleaning hydroid material in these groups was washing in sea-water. The long stems were then cut into small pieces and extraction made in either fresh or dried condition. Alcohol or distilled water was the solvent used. A higher yield of pigment was obtained from fresh than from dried material. The crude extracts were allowed to evaporate, and during the evaporation were stirred. Since the pigments were less soluble in cold than in warm water, the extracts were chilled with ice to promote crystallisation. Crystals were obtained with great difficulty. Acid solutions of pigments from Sertularella gayi Lamaroux and S. polyzonias Linnæus yielded a small crop of crystals.

Although crystals of the pigments themselves were difficult to procure, it was relatively easy to procure their salts in crystalline form. Lead and iron salts of the pigments in the Sertulariidæ studied resembled the flavone salts of the plant flavones.

The species studied were Sertularia pumila Linnæus, Sertularia argentea 
Ellis and Solander, Sertularella gayi Lamaroux, Sertularella polyzonias Linnæus, and Thuiaria articulata Pallas.

\section{Results Obtained.}

The nature of the pigments in the Sertulariidæ had first to be studied from a purely negative view-point. They were not soluble in the fat solvents, $\mathrm{CS}_{2}, \mathrm{CCl}_{4}$, or petroleum ether, therefore they were not carotinoids. Tests for free sulphur were negative, although the hydroids turned black in death. The species Sertularia argentea, Sertularella gayi, S. polyzonias, and Thuiaria articulata blackened readily on exposure to air. The yellow pigments found did not reduce Fehling's solution, nor did they present the other characteristics of chrysomphanic acid. The pigment in the Sertulariidæ is not distributed evenly throughout the tissues but occurs in small patches. This is especially true of the yellow species. The brown species Sertularia pumila apparently has more nearly uniform distribution of colouring matter.

No pigment solutions blackened on exposure to air. The blackening of the hydroid might be due to some enzyme adsorbed on the tissues, and not dissolved with the pigment. It is also interesting to observe that the one intertidal species studied, namely, Sertularia pumila, did not blacken on exposure to air. The other species used are normally covered at all times by sea-water. The blackening may possibly be that of a pigment not soluble in the same solvents as are the flavone-like pigments.

The yellow colouring matter in Sertularella gayi Lamaroux and Sertularella polyzonias Linnæus were extremely soluble in distilled water. An animal immersed in either distilled or tap water began to lose colour from the instant it was placed in the solvent. In neutral or alkaline aqueous solutions the pigment was a lemon-yellow. The gonophores were especially rich in colouring matter. Extracts from fresh material often had a greenish yellow cast. Rhomboid pigment crystals were obtained from etherial solutions. By salt formation, type of crystal, or differential solubility tests, the pigments from these two species, Sertularella polyzonias and S. gayi, could not be separated. It is possible that these closely allied species bear a common pigment. A determination of the chemical constitution of the pigments in question is necessary before it can be said definitely whether there are one or two pigments involved.

Nearly allied to the colouring matter in the Sertularellas is the chromatophore group in the white or colourless species Sertularia argentea Ellis and Solander. This hydroid can be used as indicator for hydrogen ion concentration. It is colourless in neutral and acid solutions. The aqueous extract of the chromatophore is colourless at $\mathrm{pH} 7$, yellow at $\mathrm{pH} 8$, orange at $\mathrm{pH} 8 \cdot 5$, and finally brown in $\mathrm{pH} 10$. Extracts of these chromatophore 


\begin{tabular}{|c|c|c|c|c|c|c|c|c|c|c|}
\hline \multirow[b]{2}{*}{$\begin{array}{l}\text { Species. } \\
\text { Thuiaria articulata } \\
\text { Pallas }\end{array}$} & \multirow[b]{2}{*}{$\begin{array}{l}\text { Colour } \\
\text { in Nature. } \\
\text { orange- } \\
\text { brown }\end{array}$} & \multicolumn{3}{|c|}{ Solubility. } & \multicolumn{3}{|c|}{ Colour of metallic salts. } & \multicolumn{3}{|c|}{$\begin{array}{l}\text { Influence of } \mathrm{pH} \text { on } \\
\text { pigment colour. }\end{array}$} \\
\hline & & $\begin{array}{l}\text { Water. } \\
\text { readily }\end{array}$ & $\begin{array}{l}\text { Alcohol. } \\
\text { readily }\end{array}$ & $\begin{array}{c}\text { Ether. } \\
\text { moderately }\end{array}$ & $\begin{array}{l}\mathrm{Pb}(\mathrm{COO})_{2} \\
\text { blue }\end{array}$ & $\begin{array}{r}\mathrm{FeCl}_{3} \\
\text { brown }\end{array}$ & $\begin{array}{r}\mathrm{FeSO}_{4} \\
\text { greenish }\end{array}$ & $\begin{array}{l}\text { Neutral } \\
\text { pH } 7 . \\
\text { brown }\end{array}$ & $\begin{array}{l}\text { Alkaline } \\
\mathrm{pH} 8 . \\
\text { lemon- } \\
\text { yellow }\end{array}$ & $\begin{array}{l}\text { Acid } \\
\mathrm{pH} 6 \cdot 5 . \\
\text { colourless }\end{array}$ \\
\hline $\begin{array}{l}\text { Sertularia argentea } \\
\text { Ellis and Solander }\end{array}$ & $\begin{array}{l}\text { white or } \\
\text { colourless }\end{array}$ & readily & readily & slightly & blue & blue & greenish & colourless & $\begin{array}{l}\text { yellow (at } \\
\text { pH } 8.5 \\
\text { orange) }\end{array}$ & colourless \\
\hline $\begin{array}{l}\text { Sertularella gayi } \\
\text { Lamaroux }\end{array}$ & $\begin{array}{l}\text { lemon- } \\
\text { yellow }\end{array}$ & readily & readily & moderately & blue & greenish & blue & yellow & yellow & colourless \\
\hline $\begin{array}{l}\text { Sertularella polyzonias } \\
\text { Linnæus }\end{array}$ & $\begin{array}{l}\text { lemon- } \\
\text { yellow }\end{array}$ & readily & readily & moderately & blue & greenish & blue & yellow & yellow & colourless \\
\hline $\begin{array}{l}\text { Sertularia pumila } \\
\text { Linnæus }\end{array}$ & brown & moderately & readily & slightly & greenish & greenish & blue & brown & brown & $\begin{array}{l}\text { yellow (at } \\
\text { pH } 4 \\
\text { white) }\end{array}$ \\
\hline
\end{tabular}


in ether or alcohol were also colourless. The presence of the pigment became apparent when $\mathrm{KOH}$ or $\mathrm{NH}_{4} \mathrm{OH}$ was added to the solutions. The pigment or rather the chromatophore group was insoluble in $\mathrm{CCl}_{4}$, $\mathrm{CS}_{2}$, or petroleum ether, but was slightly soluble in ether. The presence of the pigment group in this colourless hydroid can be demonstrated by holding the hydroid over $\mathrm{NH}_{4} \mathrm{OH}$ fumes. It was by this simple method that Wheldale (1916) demonstrated the flavone in the white snapdragon.

The pigment in the Sertularia pumila was distinctly less soluble in water than were the pigments from the other species. It was insoluble in $\mathrm{CS}_{2}, \mathrm{CCl}_{4}$, and petroleum ether, even after long standing in contact with these solvents. Sertularia pumila is also a natural indicator for $\mathrm{pH}$, but its colour changes lie on the acid side of neutrality. Characteristic salts of the pigment were obtained with $\mathrm{Pb}(\mathrm{COO})_{2}, \mathrm{FeCl}_{3}, \mathrm{FeSO}_{4}$.

The orange-brown species Thuiaria articulata Pallas contained a pigment, also a natural indicator, which was readily soluble in water. Crystals were obtained from slightly acid solutions. Addition of small quantities of $\mathrm{HCl}$ to water, alcohol or ether solutions made them turbid. From these turbid solutions rhomboid crystals were obtained. The $\mathrm{pH}$ of such solutions must be controlled, for at $\mathrm{pH} 655$ the pigment was decolorised. Characteristic salts were formed with $\mathrm{Pb}(\mathrm{COO})_{2}, \mathrm{FeCl}_{3}$, and $\mathrm{FeSO}_{4}$. In solubility, crystal type, and salt formation the pigment of Thuiaria articulata resembles that found in the Sertularellas.

The accompanying table gives the chief results obtained with the pigments of the Sertulariidæ. Each of the species studied contained a watersoluble colouring matter. The pigments were all natural indicators. In solubility, crystal type, and salt formation the colours from Sertularella gayi, S. polyzonias, Sertularia argentea, and Thuiaria articulata showed marked similarity. Sertularia pumila contained a pigment which possessed properties similar to the flavones, but was distinctly less water soluble than the others studied.

\section{SUMMARY.}

1. The yellow colours of the hydroids include at least two groups, the carotinoids found in the Antennulariidæ and Haliciidæ and the flavonelike pigments that occur in the Sertulariidæ. From the literature a third group, the uradines, may be added.

2. The flavone pigments and their relatives are all water soluble and are thus distinguished from the carotinoids which are not water soluble, but may be dissolved in the usual fat solvents.

3. In the Sertulariidæ studied, a graded series of chromatophore groups and pigments was found which ranged from the colourless species Sertularia argentea Ellis and Solander, through the yellow of Sertularella gayi 
Lamaroux and S. polyzonias Linnæus, to the orange-brown of Thuiaria articulata Pallas. The brown of Sertularia pumila is probably also a flavone derivative.

4. The flavones and related pigments occur extensively in the plant kingdom. It is probable that the flavone-like pigments found in the Sertulariidæ are of plant origin.

\section{Acknowledgments.}

The results on which this paper is based were obtained at the Laboratory of the Marine Biological Association at Plymouth. I wish to thank Dr. E. J. Allen, the director of the station, for allowing me to work as guest in the Laboratory, and for his friendly co-operation throughout the course of the study. To each of the members of the staff I owe thanks for helpful co-operation, especially to Dr. W. R. G. Atkins who has also worked with pigments. Finally, to the captain and crew of the good ship Salpa, without whose aid in procuring the large quantities of material necessary for this study, this research would have been impossible, my thanks are due.

\section{LITERATURE CITED.}

1882. Blanchard, Raphä̈L. Note sur la matière bleue du rhizostome de Cuvier. Bull. Soc. Zool. de France, "r, 402-404.

1880. Colasanti, J. Il pigmento blu' delle idromedusæ. Atti acad. Med. Roma Anno 12, 18 pp.

1920. Elmhirst, R., And Sharpe, J. On the colours of the two seaanemones, Actinia equina and Anemonia sulcata. I. Environmental (Elmhirst) II. Chemical (Sharpe). Biochem. Journ., 14, 48-57, $2 \mathrm{pl}$.

1889. Fewkes, J. Walter. On a method of defence among certain Medusæ. Annals and Magazine of Natural History, 4, 342-350. Also published in Proc. Boston Soc. Nat. Hist., 34, 200-208.

1903. Fürth, Отто von. Vergleichende chemische Physiologie der niederen Tiere. Gustav Fischer, Jena, $670 \mathrm{pp}$.

1922. Fulton, J. F., jr. Animal chlorophyll. Its relation to hæmoglobin and to other animal pigments. Quart. Journ. Microscop. Sci., 66 (N.S.), 339-396.

1882. Geddes, Patrick. Further researches on animals containing chlorophyll. Nature, 303-305. 
1892. Griffiths, A. B. Physiology of the Invertebrata. Reeve and Co. London, 477 pp. See pp. 209-219.

1895. Griffiths, A. B., ext Platt, C. Sur la composition de la pélagéine. Compt. Rend. Soc. Biol. (Paris), 121, 451-452.

1926. Haurowitz, Felix, und Waelsch, Heinrich. Über die chemische Zusammensetzung der Qualle Vellela spirans. Hoppe-Seylers Zeitschr. f. Physiol. Chem. 161 : 300-317.

1931. Kropí, Benjamin. The pigment of Vellela spirans and Fiona marina. Biol. Bull. 60, 120-123.

1880. Kruckenberg, C. Fr. W. Das Antheagrün. In Vergleichende physiologische Studien. 1. Reihe, 5. Abt., 38-42, Carl Winter. Heidelberg.

1882. Kruckenberg, C. Fr. W. Die Pigmente. In Vergleichende physiologische Studien. 2. Reihe, 3. Abt., 1. Ueber das Cyanëin, 2. Beitrage zur Kenntnis der Aktinienfarbstoffe, 72-73, Carl Winter. Heidelberg.

1873. Lankaster, E. Ray. The colouring matter of Stentor coruleus. Quart. Journ. Microscop. Sci., 13, 193-142.

1898. Liversidge, A. The blue pigment in coral (Helipora corulea) and other animal organisms. Journ. Roy. Soc. New South Wales, 32, 256-268.

1881. M'Kendrick. On the colouring matter of jelly-fishes. Jour. Anat. and Physiol., 15, 261-264.

1885. MacMunn, C. A. Observations on the chromatology of Actiniæ. Philosoph. Trans. Roy. Soc. London, 176, 641-663.

1890. MacMunn, C. A. Contributions to animal chromatology. Quart. Jour. Microscop. Sci., 30 (N.S.), 51-96.

1885. MacMunn, C. A. On the chromatology of the blood of some invertebrates. Quart. Jour. Microscopical Sci., 25 (N.S.), 469-490.

1873. Moseley, H. N. On Antinochrom, a colouring matter of Actinias which gives an absorption spectrum. Quart. Jour. Microscop. Sci., 13, N.S. 143-144.

1877. Moseley, H. N. On the colouring matter of various animals and especially of the deep-sea forms dredged by H.M.S. Challenger. Quart. Jour. Microscop. Sci., 17 (N.S.), 1-23.

1922. Palmer, Leroy S. Carotinoids and related pigments. The chromolipoids. Chemical Catalogue Company, New York, $316 \mathrm{pp}$. 
1924. Palmer, Leroy, S., and Knight, Harry H. Carotin the principal cause of the red and yellow colours in Perillus bioculatus (Fab.) and its biological origin from the lymph of Leptinotarsa decimlineata (Say). Jour. Biol. Chem., 59, 443-449.

1925. Schertz, F. M. Some physical and chemical properties of Xanthophyll and the properties of the pure pigment. Jour. Agri. Res., 30, 575-585.

1925. Schertz, F. M. Some physical and chemical properties of carotin and the preparation of the pure pigment. Jour. Agri. Res., ₹ $\mathbf{0}$, $469-474$.

1925. Teissier, Georges. Changement de coloration des embryones de Clava squamata au cours de l'ontogenèse. Travaux de la Stat. biol. de Wimeraux, 9 ; also published in Compt. Rend. Congrès de l'Avanc. de Sci., 48 ${ }^{\mathrm{e}}$, Session Liège, 481-482.

1916. Wheldale, Muriel. The anthocyanin pigments of plants. Cambridge University Press, 318+xiii pp. 
